\title{
Profiles: Stanley W. Ashley
}

\author{
Stanley W. Ashley ${ }^{1}$
}

Published online: 8 May 2018

(c) Springer Science+Business Media, LLC, part of Springer Nature 2018

Success consists of going from failure to failure without loss of enthusiasm.

Winston Churchill

It is more than humbling to be invited to write an autobiographical perspective that might be of interest or value to others. Although any success I have had is largely explained by a combination of "turtle on a fencepost" and " $80 \%$ of life is showing up," I truly have had the privilege of being in "the right place at the right time"-I have lived in some amazing places with some remarkable people, and this profile will focus on them and not me.

\section{Cooperstown}

I was born in Washington, DC in 1954. My father, Charles Ashley, a pathologist, was doing his Berry Plan time at Walter Reed. Within a year we moved to Cooperstown, NY, where he took a position at the Mary Imogene Bassett Hospital. My father had done his internship there, and both my parents had fallen in love with the town and the hospital. Cooperstown is an idyllic community with a population of only about 2000, and Bassett is a unique institution. The largest employer in the county, the hospital has always had a medical staff of employed physicians dedicated to specialty health care, research, and teaching in a rural setting. For me, Bassett has always represented the best in medicine and had a profound influence on my career direction. My dad loved pathology, research, and teaching but believed enough in the institution that when the opportunity arose, he gave them up for a mainly administrative role; he served as director of Bassett from 1967 to 1984. My mother was an incredibly dedicated volunteer for the hospital and in community activities. She is probably the most positive person I have

Stanley W. Ashley

sashley@partners.org

1 Frank Sawyer Professor of Surgery, Brigham and Women's Hospital, Harvard Medical School, 75 Francis Street, Boston, MA 02115, USA ever met, and I like to think that some of those things from my parents rubbed off on me. I have four younger sisters, and we all attended the public schools in Cooperstown, where I think we received as good an education as you can in a small community.

\section{Oberlin}

I wanted something a little different for college and ended up at Oberlin in Ohio. Oberlin was founded by abolitionists, and it was both the first coeducational college in the country and the first to admit students of all races. Although it celebrates its progressive history, the academics were traditional and the students serious. There is also a remarkable school of music; as a liberal arts student, I was awed by the conservatory students' technical expertise and, in retrospect, believe this may have made medicine and ultimately surgery an appealing career direction. I majored in history but fit in all the premed requirements. I spent one summer in Cooperstown following around a urologist, Rodman Carter, who also did some general surgery and was excited by the operating room and the magnitude of the impact he had on his patients' lives. The privilege of having someone agree to let you operate on him/her and the responsibility that entailed inspired me. I also spent a summer working in the laboratory of Theodore Peters, also in Cooperstown, a biochemist who had devoted his career to understanding serum albumin; I enjoyed the scientific process but at the time could not see myself doing it in the future. After Oberlin, I took what would now be called a gap year: eight months on an oil rig in the Gulf of Mexico and the rest at a Vermont ski area. Although I loved working outside, I was ready to go back to school by the following fall.

\section{Cornell}

I had a few choices but ended up at Cornell Medical College; I had not really lived in a city, and it was also my father's alma mater. After a year "off the grid," I was initially 
intimidated by my incredibly accomplished classmates, including Elizabeth Nabel, who is now president of the Brigham and Women's Hospital and my boss. I continue to be impressed by what a small-world medicine is-my upper-class adviser was Thomas Lee, who now splits his time between practice at the Brigham and serving as chief medical officer at Press Ganey, and I played rugby with David Sugarbaker, who was chief of thoracic surgery at the Brigham for much of my tenure. Cornell was an incredibly stimulating place with inspiring faculty-Jeremiah Barondess and Martin Gardy in medicine, Graham Hawkes in obstetrics, George Gray in pathology, among a long list. With each successive clinical clerkship, I thought I had found my calling. It was relatively late in my third year that I did my surgery rotation, and I was hooked immediately-the surgical decision making, technical challenge, impact on patients, and camaraderie (and maybe even a touch of masochism), combined with some superb mentors-G. Tom Shires, Peter Canizaro, and an unbelievable group of surgical residents-all conspired to push me toward surgery. I remember Canizaro giving an interactive discussion of surgical decision making in the management of peptic ulcer, weighing recurrence rates with morbidity that varied based on the patient's specific characteristics, what we today would call patient-centered risk calculation. This kind of thought process combined with my feeling that the general surgeon was really a complete physician, not only doing the surgery but also caring for the patient's other conditions from intensive care unit to recovery, sold me on general surgery. Shires was great about advice on programs, and I ended up ranking Washington University in St. Louis at the top of my list; Samuel Wells, Jr., from Duke, had been recently named as their new chair, and Shires thought it would soon be one of the top programs in the country again.

\section{Washington University}

Barnes Hospital was an incredible place to train that only improved with Wells' arrival. He was a strong taskmaster with the highest standards, and there is nothing more exciting than to be part of a new chair's efforts to build a program. At that time, there were some giants on the faculty-Eugene Bricker, Harvey Butcher, Walter Ballinger, Charles Anderson, William Monafo, Laurence Cheung, and Gregorio Sicard, and Wells made some equally strong additions-Ira Kodner, Robert Fry, James Becker, William Kraybill, Marvin Lopez, Wayne Flye, Jeffrey Moley, Larry Kaiser, and Nathaniel Soper. I entered the program thinking that I wanted to be a community surgeon, but after making the pyramidal system's "cut," I was told that I was going to the laboratory and to which one. Larry Cheung was a superb mentor-he had grown up in mainland
China, gone to Salt Lake for internship, and then joined the University of Utah residency, where he was mentored by Frank Moody. Larry was primarily a surgical investigator and had a set of rules for success in academic surgery, some from Frank and some of his own, that I was exposed to quickly. With David Soybel, who joined me in the laboratory the second year, we had a unique opportunity to do real basic science and learned to write abstracts, papers, and grants and present at meetings. There were two main themes to our work: the relationship between gastric mucosal blood flow and stress ulceration, which we studied in a canine model $[1,2]$, and gastric mucosal ion transport, which we examined with microelectrodes in a Necturus model [3, 4] that Luis Reuss, a physiologist at Washington University and collaborator, had developed in the gallbladder. This was an incredibly exciting and productive experience; I ended up spending three years in research and by the last year was both excited about and prepared to start my own laboratory. It was during my research that I married Vicki McCullough. I returned to the hospital for three more clinical years. Our son Thomas was born during my chief resident year.

Although I loved gastrointestinal surgery, by the time I finished training, Larry Cheung had left to become Chair at University of Kansas, and I thought the priority should be a position where I had the support to start my research. Surgeons were beginning to incorporate molecular biology into their methodology, and Dr. Wells encouraged me to join the efforts he was making to identify the genes for the multiple endocrine neoplasias (MENs). I applied for and was awarded a Career Development Award from the Society for Surgery of the Alimentary Tract (SSAT) to work on MENI; I joined the laboratory of Daniella Gerhard, an expert on chromosome 11, where the genetic abnormality in MENI had been localized, in the Department of Genetics at Washington University as basically a postdoctoral fellow. I had clinical appointments at the John Cochran VA and Barnes Hospitals. The research was an unbelievable learning experience, looking for deletions in MENI tumors [5] and traveling around the country to draw blood for DNA isolation from several large MENI cohorts that Dr. Wells had identified. At the same time, Nat Soper was starting the first laparoscopic cholecystectomy program in Missouri and involved me [6,7]. This was also the period when lithotripsy was being utilized for cholelithiasis, and, with the availability of less invasive therapies, there was a flood of patients seeking treatment for symptomatic disease that many had lived with for years. Although in retrospect these were both unbelievable opportunities to acquire new skills, I did not really feel as though I owned either effort, was busier than I had been as a chief resident, and was not seeing my new son; I also developed Graves' disease, successfully treated with radioiodine, but I felt as though something had to give. 


\section{UCLA}

In my second year on the faculty at Barnes, I decided to look around for another position. I was tempted by a private practice job in Bryn Mahr, Pennsylvania, but Michael Zinner, who was in his second year as chair of surgery at UCLA, convinced me to give academics another try. The decision was the right one: UCLA was an incredibly exciting place to be a young GI surgeon. In addition to Mike, William Longmire, Ronald Tompkins, Howard Reber, Edward Passaro, and Joel Roslyn were committed mentors. Mike was an unbelievable recruiter, and Julie Frieshlag, Charles Brunicardi, Rolando Rolandelli, David McFadden, H. Gil Cryer, Edward Livingston, and I all came on the faculty over his first few years. At no other time in my career have I had more fun-we were all trying to start our research efforts and practices and were part of what Mike was trying to build at UCLA. Mike has always been a terrific mentor-he gives you as much line as you want but is always ready to pull it in when and if you need him to. Both Mike and Howard Reber were eager to involve me in their laboratories and had teams of research residents looking for projects. With Mike, I was able to start a series of studies examining adaptation of intestinal transport $[8,9]$ using some of the molecular techniques I picked up in St. Louis. With the initial funding and support from CURE (Center for Ulcer Research and Education) and John Walsh and collaborations with Ernest Wright and Jared Diamond in physiology, I was able to secure a $\mathrm{K}$ award from NIDDK that would subsequently lead to several cycles of RO1 funding. Dave McFadden subsequently joined the laboratory, and it was an incredible collaboration. We had a series of terrific residents doing their research time-O. Joe Hines, Anton Bilchik, A. James Moser, Edward Whang, and James Dunn-who each were remarkably productive. With Howard at the VA, I also became involved in studies examining blood flow in chronic pancreatitis using technology that I had used in the stomach [10,11]; again, the residents made all the difference-Carlos Alvarez, Michael Lewis, John Lane, and others. I quickly received a RAG and then a Merit Review award from the VA. In parallel, my clinical practice took off-the group at UCLA was just starting with laparoscopic techniques, so I again brought something from my previous experience. Mike also had a steady stream of complex GI referrals and, with his administrative responsibilities, needed help; it was basically an advanced GI surgical fellowship.

In 1994, Mike move to Boston to become the chair at Brigham and Women's Hospital. He had been the program director of the surgical residency at UCLA, and, when he left, I had stepped into that role. Education has been one of the most fulfilling parts of my career. The residents at UCLA were outstanding and taught me a great deal. They are too numerous to name, but many have become life-long friends. Being program director when the residents are so talented is just a great job, and I loved it.

\section{Brigham}

Although UCLA was professionally a terrific experience, living in LA with young children was less so. We had bought a fixer-upper in Grenada Hills but still had a lot of work to do when the 1994 Northridge earthquake leveled both the Sepulveda VA, where I was working, and home values in our neighborhood. We decided to pay to terminate our mortgage and rent in West LA instead. Our daughter, Eliza, was born shortly after the earthquake. In 1996, Mike and the Brigham offered me a great position and some help with purchasing a new home in Boston; that combination was impossible to turn down.

Although we missed the year-round sunshine, the move to the Brigham was another great opportunity. In addition to working with Mike again, there was another amazing multigenerational group of colleagues, including the two previous chairs, Frances Moore and John Mannick, and a solid cadre of senior and mid and late career faculty-Frances Moore, Jr, David Brooks, Timothy Eberlein, Samuel Singer, Robert Osteen, Herbert Hechtman, David Sugarbaker, Elof Eriksson, and Jerome Ritchie. Not unlike some other Boston programs, the Brigham at the time seemed somewhat inbred, and Mike and his recruits brought some change to that paradigm. This trend has continued to the present. At the time, Boston had no lack of GI surgeons, but I took a part-time position with the Harvard Community Health Plan (HCHP, an independent mulitspecialty group practice based at the Brigham under the leadership of Gordon Vineyard) and immediately had a complex and relatively broad GI practice-at the time I was their only surgeon doing complex laparoscopic and ileoanal procedures - so I became busy clinically almost overnight.

The Brigham also offered many opportunities for collaboration-James Madara, Elizabeth McCormick, Peter Banks, Danny Jacobs, and Herbert Hechtman were among a long list of collaborators. Danny and I actually shared the Surgical Metabolism Laboratory in the old Thorn building until Danny moved to Creighton to become chair of surgery. We had a string of productive residents including Jasleen Kureeja, Robert Shen, Ali Tavakkoli, Alex Perez, James Gardner Thorpe, Hiromichi Ito, Flavio Rocca, and Mark Duxbury. Edward Whang and then Ali Tavakkoli joined the laboratory as junior faculty, helped me run it, and successively became independent investigators; Ali runs the laboratory today. Areas of interest included intestinal 
adaptation and glucagon-like peptide 2 [12, 13]; Ed's focus was on pancreatic cancer [14] and eventually, under Ali's direction, changes in glucose transport after bariatric surgery [15]. We also had a unique opportunity to collaborate with Peter Banks around his incredible experience with necrotizing pancreatitis $[16,17]$.

The Brigham residency, like that at UCLA, attracts outstanding physicians. Mary Klingensmith, Bruce Hall, Martin Weiser, Robert Cima, Gilbert Upchurch, and Holly Hedrick were all at various stages in the residency when I arrived, and we continued to recruit a talented group too long to list. I became program director-again a mostly easy job at the Brigham. Facing the 2003 duty hour restrictions, I stepped back and let the residents plan and operationalize. We had an MIT Sloan School of Business PhD candidate, Kate Kel$\log$, spend a year with us studying the process for her thesis, and although it didn't happen overnight, we learned a lot about organizational and cultural change and eventually got there [18]. Between UCLA and the Brigham, I was program director for almost a decade and a half during a time of significant and much-needed change in surgical training; by the time I finished as program director in 2011, there were more women than men in the program, and almost a third of the residents were from underrepresented minorities.

At about the time I arrived at the Brigham, I began looking at surgical chairs and over the years I've probably looked more than anyone I know (there are a couple for which I have been a candidate for three different cycles); there are pros and cons to every position but I thought naively that if I waited until the next opportunity, it was going to be perfect. In retrospect, I was fooling myself, and the reality was that I did not want to leave what had to have been one of the best surgical jobs in the country. Mike also made me vice chair of the department of surgery and was always willing to hand off to me anything I wanted to do-I was able to become involved in strategy, planning, recruitment and retention, promotion, network development, and quality and safety. In addition, I became chief of surgery for what had been HCHP, now Harvard Vanguard Medical Associates. My children were five years apart, and there was about a 10-year period during which one was in high school and reluctant to move.

In 2011, I was asked to take the position of chief medical officer and senior vice president for medical affairs at the Brigham. It was not a role I had previously considered, but my predecessor, Anthony Whittemore, another surgeon, encouraged me to consider it. It was an interesting combination of activities, representing hospital administration to physicians and vice versa, with a growing role in promoting physician engagement in hospital operations and quality and safety. The role came with a broad array of responsibilities, including physician leadership for interdisciplinary care and oversight of credentialing and privileging, professionalism, GME, and even the pharmacy. I decided to try it and the job stuck - I think the diversity fit and, although about a third of my time has been spent on professionalism issues, I have tried to "have the back" of the medical staff and have felt like I have made a real difference. I have now been in this role eight years, and it has started to seem as though I have seen most problems at least once before. There have also been a series of crisis events; however-the Boston Marathon bombings [19]; the murder of Michael Davidson, one of our cardiac surgeons who had trained at the Brigham, by a patient's son [20]; and a near strike by our nursing unionthat stretched us to the limit and left the institution and me a little different afterward.

\section{Service}

I have also been fortunate enough to have a number of national roles throughout my career. Working with colleagues from around the country on national issues has been both a sometimes needed break from my day job but also an opportunity to make a larger contribution. Probably most significant have been the SSAT, the American Board of Surgery (ABS), and the Accreditation Council for Graduate Medical Education (ACGME).

The SSAT has always been my academic home - it brings GI surgeons from all the subspecialties together and meets during Digestive Disease Week with colleagues from gastroenterology and GI basic science. I was introduced to the SSAT by my mentors, presented my first paper there, and have continued to be engaged throughout my career; I count many of its members as my closest colleagues and friends. My most important roles have been as chair of the membership committee, member of the board, secretary, and, this year, president, with the hope of initiating a strategic planning process that will define a new vision for the future of the society.

My service to the ABS has included eight years as an active director and six years as a senior director, still giving board oral examinations. In addition to developing written and oral examination and administering orals, ABS directors also have a policy role. Serving on the board is an incredible opportunity-you work closely with a relatively small group of colleagues for almost six weeks a year, and you have a real opportunity to make a difference. I first chaired the In-Training Examination Committee and then the General Surgery Residency Committee, for which I was vice chair and then chair. Although I do not believe any director can claim responsibility for board actions, during my tenure there were several areas in which I feel I made a significant contribution. The one of which I am most proud was a major role in initiating the development of the national general surgery curriculum. I also helped stimulate a reconsideration of requirements around time of service by permitting residents 
to have prolonged parental leave two times during residency. We were also able to codify a reentry process for surgeons with lapsed certificates; I believe the ABS was the first board to do this. With other members, I was responsible for crafting a significant portion of the first iteration of the general surgery milestones and was able to initiate a policy change to permit residents to devote one year, distributed over the PGY 3-5 years, to a single subspecialty area.

I currently serve on the Board of Directors of ACGME. This again has been a special opportunity to "do the good work" with a small group of colleagues, this time from across specialties. I was a member of the Phase 1 (work hours) Common Program Requirements Task Force that has initiated, through a series of new requirements, a needed dialogue around resident well-being. I am now co-chair of the Phase 2 Task Force that is revising the rest of the common requirements and a member of the Physician Wellness Task Force.

One of the unique privileges of an academic career is the diversity of options-I have been able at times to be most focused on research and at others to be focused on clinical care, education, and, most recently administration and service. I have loved this variety and would be proud if the adage, "A jack of all trades is a master of none, but oftentimes better than a master of one.", was at least a "sometimes." In the near future, I plan to step down as chief medical officer, and I am pleased that I can return to practice, teaching, and research for as long as I remain healthy. Medicine continues to be an honor and a privilege.

The life of every man is a diary in which he means to write one story, and writes another; and his humblest hour is when he compares the volume as it is with what he vowed to make it.

JM Barrie, The Little Minister, 1891

\section{References}

1. Ashley SW, Cheung LY. Measurements of gastric mucosal blood flow by hydrogen gas clearance. Am J Physiol. 1984;247:339-345.

2. Ashley SW, Sonnenschein LA, Cheung LY. Focal gastric mucosal blood flow at the site of aspirin-induced ulceration. Am J Surg. 1985;49:53-59.

3. Ashley SW, Soybel DI, Cheung LY. Microelectrode studies of Necturus antral mucosa: II. Equivalent circuit analysis. Am J Physiol. 1985;248:G574-G579.
4. Ashley SW, Soybel DI, Cheung LY. Measurements of intracellular $\mathrm{pH}$ in Necturus antral mucosa by microelectrode technique. Am J Physiol. 1986;249:G625-G632.

5. Radford DM, Ashley SW, Wells SA Jr, Gerhard DS. Loss of heterozygosity of markers on chromosome 11 in patients with multiple endocrine neoplasia syndrome type I. Cancer Res. 1990;50:6529-6533.

6. Soper NJ, Barteau JA, Clayman RV, Ashley SW, Dunnegan DL. Laparoscopic versus standard open cholecystec-tomy: Comparison of early postoperative results. Surg Gynecol Obstet. 1992;174:114-118.

7. Soper NJ, Stockmann PT, Dunnegan DL, Ashley SW. Laparoscopic cholecystectomy: The new 'gold standard'? Arch Surg. 1992;127:917-923.

8. Bilchik AJ, Hines OJ, Zinner MJ, et al. Peptide YY (PYY) is a physiologic regulator of water and electrolyte absorption in the small bowel in vivo. Gastroenterology. 1993;105:1441-1448.

9. Hines OJ, Bilchik AJ, Zinner MJ, et al. Adaptation of the $\mathrm{Na}^{+} /$ glucose cotransporter following intestinal resection. J Surg Res. 1994;57:22-27.

10. Reber HA, Karanjia ND, Alvarez C, et al. Pancreatic blood flow in chronic pancreatitis in cats. Gastroenterology. 1992;103:652-659.

11. Ashley SW, Schwarz M, Alvarez C, Nguyen TN, Vdovenko A, Reber HA. Pancreatic interstitial pH regulation: Effects of secretory stimulation. Surgery. 1994;115:503-509.

12. Jasleen J, Shen R, Tavakkolizadeh A, et al. Signaling mechanisms of glucagon-like peptide 2 (GLP-2)-induced intestinal epithelial cell proliferation. J Surg Res. 2000;90:13-18.

13. Tavakkolizadeh A, Berger UV, Shen KR, et al. Diurnal rhythmicity in intestinal SGLT1 function, $\mathrm{V}_{\max }$, and mRNA expression topography. Am J Physiol. 2001;43:209-215.

14. Duxbury MS, Waseem $\mathrm{T}$, Ito $\mathrm{H}$, et al. Ghrelin promotes pancreatic adenocarcinoma cellular proliferation and invasiveness. Biochem Biophys Res Commun. 2003;309:464-468.

15. Balakrishnan A, Stearns AT, Rounds J, et al. Diurnal rhytmicity in glucose uptake is mediated by temporal periodicity in the expression of the sodium-glucose cotransporter (SGLT1). Surgery. 2008;143:813-818.

16. Ashley SW, Perez A, Pierce EA, et al. Necrotizing pancreatitis: A contemporary analysis of 99 consecutive cases. Ann Surg. 2001;234:572-580.

17. Perez A, Whang EE, Brooks DC, et al. Is the severity of necrotizing pancreatitis increased in extended necrosis and infected necrosis? Pancreas. 2002;25:229-233.

18. Kellogg KC, Breen E, Ferzoco SJ, Zinner MJ, Ashley SW. Resistance to change in surgical residency: An ethnographic study of work hours reform. JACS. 2006;202:630-636.

19. Gawande A. Why Boston's hospitals were ready. The New Yorker. https://www.newyorker.com/news/news-desk/why-bostons-hospi tals-were-ready. Accessed 17 Apr 2013.

20. Goralnick E, Zinner MJ, Ashley SW. A death in the family: Lessons from a tragedy. Ann Surg. 2016;263:230-231. 